Richard Brook

Bloomsburg University, USA

ORCID: 0000-0002-1811-663X

e-mail: richardb@ptd.net

\title{
Berkeley, Newton, Explanation, and Causation
}

DOI: http://dx.doi.org/10.12775/RF.2018.034

I argue in this paper that Berkeley's conception of natural law explanations, which echoes Newton's, fails to solve a fundamental problem, which I label "explanatory asymmetry"; that the model of explanation Berkeley uses does not distinguish between explanations and justifications, particularly since Berkeley denies real (efficient) causes in nonminded nature. At the end, I suggest Berkeley might endorse a notion of understanding, say, in astronomy or mechanics, which could be distinguished from explanation.

In De Motu § 37 Berkeley writes:

A thing can be said to be explained mechanically then indeed when it is reduced to those most simple and universal principles, and shown by accurate reasoning to be in agreement and connection with them. For once the laws of nature have been found out, then it is the philosopher's task to show that each phenomenon is in constant conformity with those laws, that is, necessarily follows from those principles. In that consist the explanation and solution of phenomena and the assigning their cause, i.e. the reason why they take place (my emphasis). ${ }^{1}$

Some comments on the passage are important: First; "constant conformity" means showing that the phenomena can be deduced ("solved")

1 I use the Works of George Berkeley, Bishop of Cloyne, edited by A. A. Luce and T. E. De Motu, vol. 4 (1721; London: Thomas Nelson and Sons Ltd., 1951) and The Principles of Human Knowledge, vol. 2 (1710, 1734; London: Thomas Nelson and Sons Ltd., 1949). 
from wider generalizations. In DM $\S 35$ Berkeley notes the purpose of a mathematical physics is to give the "solution," not the "efficient cause of particular phenomena." "Solution" here means solving an equation, or more broadly, a mathematical deduction. Second; in the passage Berkeley carefully takes "cause" to mean reason for something, as opposed to efficient cause. Only spirits (minds) he believes strictly cause events, that is, make them happen or bring them about, as opposed to being simply correlated with them. Third; implicit here, though explicit elsewhere, the ultimate laws, from which phenomena are deduced, take mathematical form. In De Motu § 38 Berkeley says:

In mechanics also [as with geometry] notions are premised, i.e. definitions and general statements about motion from which afterwards by mathematical method conclusions more remote and less general are deduced. (also § 42)

Though there are differences, Berkeley models his discussion after Newton who writes in the Principia:

But I consider philosophy rather than arts and write not concerning manual but natural powers, and consider chiefly those things which relate to gravity, levity, elastic force, the resistance of fluids, and the like forces whether attractive or impulsive; and therefore, I offer this work as the mathematical principles of philosophy, for the whole burden of philosophy seems to consist in this-from the phenomena of motions to investigate the forces of nature, and then from these forces to demonstrate the other phenomena. ${ }^{2}$

Accused by contemporaries like Leibniz of making gravity an occult quality, meaning some unobservable power, ultimately explanatorily vacuous, a charge Berkeley echoed, Newton believed gravity a real centripetal force, though its mechanism of action remained unexplained. In the familiar "General Scholium" (second edition) at the end of Book Three of the Principia he writes:

Hitherto we have explain' $d$ the phaenomena of the heavens and of our sea, by the power of Gravity, but have not yet assign'd the cause of this power. Gravitation towards the Sun, is made up out of the gravitations towards the several particles of which the body of the Sun is compos'd; and in receding from the Sun, decreases accurately in the duplicate proportion of the distances, as far as the orb of Saturn ... But hitherto I have

2 Isaac Newton, Principia (1729), transl. Florian Cajori (Berkeley: University of California Press, 1962) from Andrew Motte (1729), XVII. See also the more recent translation of the Principia by Bernard Cohen and Anne Whitman (Berkeley: University of California Press, 1999). 
not been able to discover the cause of those properties of gravity from phaenomena, and I frame no hypotheses ... And to us it is enough, that gravity does really exist, and act according to the laws which we have explained, and abundantly serves to account for all the motions of the celestial bodies, and of our sea (my emphasis). ${ }^{3}$

Although Berkeley denied real forces exist in nature, his model of explanation again closely follows Newton. For example, in Principles § 104, an earlier work, he writes:

That bodies should tend towards the center of the earth, is not thought strange, because it is what we perceive every moment of our lives. But that they should have a like gravitation towards the center of the moon, may seem odd and un-accountable to most men, because it is discerned only in the tides. But a philosopher, whose thought takes in a larger compass of Nature, having observed a certain similitude of appearances, as well in the heavens as the earth, that argue innumerable bodies to have a mutual tendency towards each other, which he denotes by the general name attraction, whatever can be reduced to that, he thinks justly accounted for (Berkeley's emphasis).

The "philosopher" is Newton. Both take general laws, expressed mathematically, to account for or explain more specific regularities, for example, planetary orbits or tidal variation. We have something comparable to what has been termed "the deductive-nomological" [DN, or "covering law"] model of explanation. For instance, from the inverse square law of gravity, and some added assumptions, we can deduce Kepler's first and second laws of motion; orbiting bodies move in ellipses, and the planets sweep out equal areas in equal times.

The DN model has well known difficulties. ${ }^{4}$ I focus on one, whether instances of the formal model to be an explanation appeals, at least implicitly, to causes. Taken just as a logically sound argument, the DN model will not distinguish explanations of why something occurred from justification of claims that it occurred. Here is a familiar example of the latter. We can deduce a flagpole's length from the following; the length of its shadow the angle light rays makes with the pole and some Euclidean geometry. The pole's length hasn't been explained, although the argument gives evidence it indeed has that length. On the other hand, given the ray's angle and the flagpole's height, I deduce and thereby explain the shadow's length since I have given its cause.

3 Newton, Principia, 1962, 546-547.

4 The DN model's formulation is attributed to Carl Hempel and Paul Oppenheim in their 1948 article "Studies in the logic of explanation," Philosophy of Science 15, no. 2 (April 1948): 135-175. 
I note that with a shift of interest from ontology to epistemology, what served as an explanation of why something is the case can serve as a justification for a claim it is the case. Illustrating the second use, the geometrical proof of the shadow's length can give further evidence for the claim it has length X, if, say, on other grounds I believed its length was X. So, the identical DN form, used to explain why something is the case can, for someone else, serve as justification for her claim it is the case. However, regardless of one's interests, the reverse is not true. If we take, as premises, the length of the pole's shadow, and principles of Euclidean geometry, we can, again, deduce the pole's length but haven't explained why it has that length.

In purely mathematical proofs no such asymmetry exists. It is simply our interests which determine whether a proof serves as an explanation or a justification. Here is an example. If I assume, as a premise, the sum of the angle theorem for triangles, I could (with other postulates and proved theorems) then deduce that the sum of the interior angles between two parallel lines cut by a transversal equals two right angles. Alternatively, if I take, as premise, that the sum of the interior angles between two parallel lines cut by a transversal is two right angles, I couldas is usually done-deduce that the sum of the angles of a triangle is two right angles. ${ }^{5}$ In either case, depending on whether one's interest is why something is true, or what the evidence is for its truth, the premises serve as either explanation of, or evidence for, the conclusion.

Why symmetry exists between explanation and justification for any Euclidean proof, but not in the pole example appears intuitive. Deriving the pole's length from its shadow does not give its cause. In the more purely mathematical case, (the geometry example above) causes are not involved. In natural philosophy then, it seems explanations require the explananda to give the cause of the explanandum.

So, we have a puzzle; call it the "flagpole puzzle." (FP). Assuming it is true that various "phenomena" (Newton's term), e.g. Kepler's laws, Galileo's law of free fall and the law of the pendulum can, with some other premises, be deduced from the inverse square law of gravity, why should the latter, assumed true, explain those planetary and mechanical laws? The ordinary answer is a force-in this case gravitational attraction - which causes the phenomena.

I consider two contemporary attempts to solve the FP puzzle which argue for non-causal explanations in science. Perhaps one or both might support Berkeley's non-causal use of the DN model. The first is from

5 A referee noted that, for an Aristotelian, the explananda are better known than the explanandum. But in the flagpole case, though the length of the shadow is better known than the length of the pole, a deduction with the shadow's length as premise, and the pole's length as conclusion, does not explain that length. 
Lina Jannson's article: “Explanatory Asymmetries: Laws of Nature Rehabilitated." Jannson gives an additional example to FP illustrating the explanatory asymmetry of DN.

... while the acceleration experienced by one of two gravitating bodies can be explained by the existence of a distant mass, the mass of that distant body cannot similarly be explained by the acceleration. ${ }^{6}$

She notes in general: "Without a solution to the problem of explanatory nonsymmetry, law-based accounts [of explanation] cannot even get off the ground" To solve FP without appeal to causes Jannson introduces the notion of "conditions of applicability." For example, the conditions of applicability in FP are the following; the sun is at a certain height, it makes a specific angle with the pole, and the shadow has a definite length. Changing one condition changes the others. On cloudy days the pole's shadow in fact disappears entirely. On the other hand, some values, for example, the length of the flagpole are not sensitive to (dependent on) changes in those other values. Its length, then, is not explained for Jannson by reference to those values. She writes:

The basic intuition that I will make use of is very simple. The difference between mere description of a phenomenon and an explanation of that same phenomenon lies in whether information about what the phenomenon depends on has been provided. For example, the length of the shadow does not explain the height of the flagpole since the height of the flagpole does not depend on the length of the shadow. However, the height of the flagpole can explain the length of the shadow since that length depends on the height of the flagpole... (author's italics, my underlining). ${ }^{7}$

What Jannson calls "mere description" can be taken as comparable to what I call "justification." We can justify a claim about the flagpole's length by appealing to geometry, the length of the shadow, and the angle the sun's rays make with the pole. But this doesn't explain the pole's length.

Yet, Jannson's account seems to me ultimately a causal account. True, not all dependency relations exhibit causality; for example, theorems in pure mathematics depend on but are not caused [except when cause just means explanation] by the postulates. But the cases Jannson describes, pole shadows depending on pole length, but not the reverse, and a body's gravitational acceleration depending on mass, but not the reverse, describe classic causal relations. Indeed, acceleration of bodies

6 Lina Jannson "Explanatory asymmetries: laws of nature rehabilitated," The Journal of Philosophy CXII, no. 11 (November 2015): 577-599.

7 Ibidem, 587. 
towards each other, she might have noted, is different in molasses than in air, but their masses remain the same. The fact that acceleration, but not masses, depends on changes in medium density, suggests increased density causes the loss of acceleration. ${ }^{8}$

As a second non-causal theory of explanation, using the work of Phillip Kitcher, I consider the "unificationist" or systematization account of explanation. In "Explanatory Unification and the Causal Structure of the World" Kitcher writes:

Science advances our understanding of nature by showing us how to derive descriptions of many phenomena, using the same patterns of derivation again and again, and, in demonstrating this, it teaches us how to reduce the number of types of facts we have to accept as ultimate (or brute). ${ }^{9}$

This passage echoes Berkeley's view of the Newtonian system, particularly how the laws of motion and of gravity unify what seemed disparate phenomena, in this case Kepler 's laws, the law of free-fall, etc. Berkeley writes in DM § 38:

The human mind delights in extending and expanding its knowledge; and for this purpose general notions and propositions have to be formed in which particular propositions and cognitions are in some way comprised, which then, and not till then, are believed to be understood. Geometers know this well. In mechanics also notions are premised, i.e. definitions and general statements about motion from which afterwards by mathematical method conclusions more remote and less general are deduced. And just as by the application of geometrical theorems, the sizes of particular bodies are measured, so also by the application of the universal theorems of mechanics, the movements of any part of the mundane system, and the phenomena thereon depending, become known and determined. And that is the sole mark at which the physicist must aim.

8 Jannson uses a dependency example she claims is more clearly not causal - but I think the case is too tentative and, in fact, is not pursued by her; that the stability of planetary orbits depends on the dimensionality of space and time and not vice versa. And then there are possible cases where someone's intentions explain the length of the pole in the following way: Assume the shadow tells us the length the builder desired, and that desire explained her construction of the pole, thus explaining its length. A causal explanation Berkeley might support, appealing as it does to volition, but a type too limited in extension to explain, in general, the measures of things.

9 Phillip Kitcher, "Explanatory Unification and the Causal Structure of the World," in Scientific Explanation, edited by Philip Kitcher, and Wesley C. Salmon, Minnesota Studies in the Philosophy of Science (Minneapolis: University of Minnesota Press, 1989), 432. 
I note the obvious criticism - one discussed below by Kitcher-of the above. If we are thinking of explanations in natural philosophy, the flagpole puzzle remains. Suppose that with respect to a set of generalizations, the members of which were formerly thought independent of each other, we can now in fact derive them from fewer laws of wider scope. Why should that deduction explain the original set? About the Newtonian system, the ordinary thought is the inverse square law of gravitation and the basic laws of motion explain, say, Kepler's planetary laws, because the inverse square law mathematizes how gravity causally acts on bodies. The unificationist account, then apparently fails, as all DN accounts, considered just in terms of the DN model's formal structure to distinguish explanations from justifications. Kitcher recognizes the flagpole problem writing:

Because the invocation of causal dependency is so obvious a response to the problems of asymmetry, it is useful to make explicit the kinds of considerations that made that response appear unavailable. One central theme of the present essay is that there is a tension between two attractive options. Either we can have a straightforward resolution of asymmetry problems, [e.g. FP case] at the cost of coming to terms with epistemological problems that are central to the empiricist tradition, or we can honor the constraints that arise from empiricist worries about causation and struggle to find some alternative solution to the asymmetries (my emphasis). ${ }^{10}$

The cost of the "straightforward" causal account of explanation is discarding Hume's analysis of causation Kitcher thinks central to empiricism. ${ }^{11}$ In fact, a strain in contemporary history of philosophy of science takes Berkeley to anticipate positivists like Ernst Mach, and others, who deny forces are real. Karl Popper and John Earman claim the historical tie between Berkeley and Mach is that both share the positivist tradition in physics and philosophy of science that rejects appeal to entities - in this case forces - thought, in principle, (as Hume thought about causation) to be unobservable. ${ }^{12}$

Berkeley writes in his earlier Principles of Human Knowledge: (§ 105)

If therefore we consider the difference there is betwixt natural Philosophers and other men, with regard to their knowledge of the Phenomena, we shall find it consists, not in an exacter knowledge of the efficient cause that produces them, for that can be no other than the will of a spirit, but only in a greater largeness of comprehension, whereby analogies, har-

10 Ibidem, 4.

11 Ibidem, 80 .

12 The discussion of Popper and others concerns Berkeley's critique of Newton's defense of absolute motion and absolute space in the Principia. See Cohen and Whitman trans., op. cit. 408-412. 
monies, and agreements are discovered in the works of Nature, and the particular effects explained, that is reduced by mathematics to general rules (my emphasis).

It is not entirely clear what Berkeley means by "analogies, harmonies, and agreements" but I take it Newton's synthesis would be an example of this "largeness of comprehension" in which Kepler's laws, the law of free fall, and the law of the pendulum, are deducible from the general laws of motion plus the inverse square law of gravity. In any case, as critics of Kitcher (and Kitcher himself) observed, unless we simply identify systemization or unification with explanation, the problem of asymmetry - the 'flagpole problem' - remains. Why again should deducing a set of formerly unexplained laws from a more general law explain the former?

To take another example of the FP problem, the inverse square law of gravity can be deduced, with other assumptions, from Kepler's third law. ${ }^{13}$ This, in an epistemological context, counts for the law's truth, but does not explain its existence. That is, we have not explained why there is a centripetal force at all. So, the asymmetry problem apparently remains.

Yet, taking a cue from Kitcher, we might defend Berkeley by distinguishing understanding from explanation. Discussing Michael Friedman, Kitcher writes:

Friedman argues that a theory of explanation should show how explanation yields understanding, and he suggests that we achieve understanding of the world by reducing the number of facts we have to take as brute. ${ }^{14}$

We might go somewhat further than Kitcher (and Friedman) and actually divorce explanation from understanding. Understanding will be tied to unification, where unification involves showing a number of formerly disparate phenomena, for example, Kepler's planetary laws, follow from the laws of motion, (e.g., F = MA) and the law of gravity. However, unification per se, though perhaps giving understanding, will not be said to explain those phenomena. For Newton, on the other hand, a force, expressed by the inverse square rule, causes and thus both explains the phenomena above, and, unifies them as examples of gravitational attraction.

In addition, with respect to unification as constituting the nature of scientific explanation, the following counter-example of Eric Barnes

13 A discussion of the derivation is found in Cohen and Whitman, ibidem, 67.

14 Michael Friedman, "Explanation and scientific understanding," Journal of Philosophy 71, no. 1 (January 1974): 5-19. 
is perhaps relevant. Barnes notes that in a Newtonian Universe we can, in principle, equally predict a mass particle's future state or retrodict its past state. ${ }^{15}$ And though the Newtonian system is a classic case of unification, Barnes argues that while the particle's past state can explain its present state, it seems "absurd" to believe the reverse, that its present state explains its past. This temporal asymmetry of explanation reflects, Barnes thinks, the temporal asymmetry of causation.

Conclusion. As far as I can determine Berkeley simply takes the Newtonian system - the laws of gravity, and basic laws of motion - to explain Kepler's laws, since the latter, he believes, can be mathematically deduced from the former. Thus, he might agree with Kitcher's identification of greater comprehensiveness, or understanding, with explanation. Given that Berkeley denies any strict or efficient causation in non-minded nature, this is a position he would likely have sympathy for. It does not, however, really solve the flagpole puzzle unless one could perhaps show that going from the measure (length, width, breadth) of material objects as premises, to the measure of shadows as conclusions, reduces the number of independent generalizations required, as opposed to going from the measure of shadows as premises, to the measure of objects (e.g. the pole's length) as conclusions. ${ }^{16}$ If the latter were (in the unlikely case) simpler in the sense of Kitcher and Friedman, it seems to me Berkeley would still find it odd to say we had an explanation of the pole's length.

One other point worth mentioning. ${ }^{17}$ There is certainly evidence Newton could accept God as the ultimate cause of gravitational phenomena, a position perhaps not too different from Berkeley's. Here is part of Newton's well-known letter (1692) to Richard Bently:

The last clause of your second Position I like very well. Tis unconceivable that inanimate brute matter should (without the mediation of something else which is not material) operate upon \& affect other matter without mutual contact; as it must if gravitation in the sense of Epicurus be essential \& inherent in it. And this is one reason why I desired you would not ascribe \{innate\} gravity to me. That gravity should be innate inherent

15 Eric Barnes, "Explanatory Unification and the Problem of Asymmetry," Philosophy of Science 59, no. 4 (December 1992), 564-565. If we think of a past state determining a future state, the past state is necessary and sufficient to account for the future state. This wouldn't be true if two distinct past states, at a given time, could account for a particular future state. I take it the former is the kind of determinism Laplace envisioned. A referee's comments led me to think harder, if not well, about this. For other reasons, I'm not convinced by Barnes's example.

16 Kitcher believes this option would be unsatisfactory; that it is unlikely a simpler system would deduce the measure of material objects (like length) from the measure of their shadows, than the reverse, when the object's measure served as premise, and the measure of its shadow as conclusion.

17 Suggested by a referee. 
$\&\{$ essential $\}$ to matter so that one body may act upon another at a distance through a vacuum without the mediation of anything else by \& through which their action or force $\{$ may\} be conveyed from one to another is to me so great an absurdity that I believe no man who has in philosophical matters any competent faculty of thinking can ever fall into it. Gravity must be caused by an agent \{acting\} constantly according to certain laws, but whether this agent be material or immaterial is a question I have left to the consideration of my readers (my emphasis). ${ }^{18}$

However, for Berkeley all physical laws, even the laws of impact, are merely correlations between divinely produced natural phenomena. Newton, in the above letter, was concerned more particularly with gravity's apparent action at a distance. But he does think his "System of the World," (Book Three, Principia), taken as a whole, is a powerful teleological argument for God's existence. He writes:

This most elegant system of the sun, planets, and comets could not have arisen without the design and dominion of an intelligent and powerful being. ${ }^{19}$

Berkeley would agree.

\section{Bibliography}

Barnes, Eric. "Explanatory Unification and the Problem of Asymmetry." Philosophy of Science 59, no. 4 (December 1992): 564-565.

Berkeley, George. De Motu (1721). In The Works of George Berkeley, Bishop of Cloyne, edited by A. Luce and T. E. Johnson, vol. 4, London: Thomas Nelson and Sons Ltd, 1951.

Berkeley, George. The Principles of Human Knowledge (1710, 1734). In The Works of George Berkeley, Bishop of Cloyne, edited by A. Luce and T. E. Johnson, vol. 2, London: Thomas Nelson and Sons Ltd, 1949.

Earman, John. World Enough and Space Time. Bradford: The MIT Press, 1992.

Friedman, Michael. "Explanation and scientific understanding." Journal of Philosophy 71, no. 1 (January 1974): 5-19.

Hempel, Carl, Oppenheim, Paul. "Studies in the logic of explanation." Philosophy of Science 15, no. 2 (April 1948): 135-175.

Jannson, Lina. "Explanatory asymmetries: laws of nature rehabilitated." The Journal of Philosophy CXII, no. 11 (November 2015): 577-599.

18 189.R.4.47, ff. 7-8, Trinity College Library, Cambridge, UK (The Newton Project: http://www.newtonproject.ox.ac.uk/view/texts/normalized/THEM00254; accessed December 10, 2018).

19 See his "General Scholium" to the second edition of the Principia, Cohen and Whitman translation, 939-947. 
Kitcher, Phillip. "Explanatory Unification and the Causal Structure of the World." In Scientific Explanation, edited by Philip Kitcher and Wesley C. Salmon, Minnesota Studies in the Philosophy of Science, Minneapolis: University of Minnesota Press, 1989.

McMullin, Ernan. "Galilean Idealization." Studies in History and Philosophy of Science Part A, 16, no. 3 (1985): 247-273.

Nelson, Alan. "Micro-Chaos and Idealization in Cartesian Physics." Philosophical Studies 77 no. 2-3 (1995): 377-391.

Newton, Isaac, Newton's letter to Bentley, (December 10, 1692) 189.R.4.47, ff. 7-8, Trinity College Library, Cambridge, UK (October 2007 http:// www.newtonproject.ox.ac.uk/view/texts/normalized/THEM00254; accessed December 10, 2018).

Newton, Isaac. Principia, (1729), Trans. Bernard Cohen and Anne Whitman, Berkeley and Los Angeles: University of California Press, 1999.

Newton, Isaac. Principia (1729). Translated by Florian Cajori. Berkeley: University of California Press, 1962.

Popper, Karl. "A note on Berkeley as precursor of Mach." British Journal for the Philosophy of Science 4, no. 13 (1953): 26-36.

\section{Summary}

Berkeley notably compares his view of scientific (natural law) explanation - particularly in mechanics, astronomy, and optics - to Newton's. The difficulty is that while for Newton basic laws, of astronomy for example, implicitly refer to efficient causes (henceforth "causes") Berkeley allows causes only in metaphysics, more specifically causality through will or volition.

Both men do think of explanation in terms of deducing particular generalizations from those more general; the deductive-nomological model of explanation (DN). Meeting its constraints, however, is not sufficient for an example of the $\mathrm{DN}$ form to be an explanation. I explore whether this is a problem for Berkeley, looking at two contemporary proposals for non-causal explanations, concluding neither is workable. It remains unresolved, then, whether Berkeley's use of the DN model should, as he wishes, count as explanatory. The main text is De Motu (1721).

Keywords: DN model, explanation, gravitation, cause 


\section{Streszczenie}

\section{Berkeley, Newton, wyjaśnianie i przyczynowość}

Berkeley explicite porównuje swoje rozumienie wyjaśnienia naukowego (dotyczącego praw natury), zwłaszcza w zakresie mechaniki, astronomii i optyki, do tego, które przedstawił Newton. Trudność polega jednak na tym, że o ile dla Newtona podstawowe prawa - na przykład w astronomii - milcząco odwołują się do przyczyn sprawczych (dalej: przyczyn), Berkeley dopuszcza istnienie przyczyn jedynie w metafizyce, a dokładniej w odniesieniu do pojęcia woli czy też chcenia.

Obaj myśliciele rzeczywiście traktują wyjaśnienie jako dedukcję poszczególnych generalizacji na podstawie generalizacji bardziej ogólnych, a więc odwołują się do nomologiczno-dedukcyjnego modelu wyjaśniania (ND). Jednakże spełnienie takich wymogów przez jakąś przykładową formułę ND nie wystarcza, aby mogła ona stanowić wyjaśnienie. Opierając się na dwóch współczesnych propozycjach rozumienia wyjaśniania niekauzalnego, w niniejszym artykule sprawdzam, czy Berkeley dostrzegał ów problem. Wniosek, do którego dochodzę, brzmi, że żadna z tych propozycji nie ma tu zastosowania. Ostatecznie zatem nie można rozstrzygnąć, czy sposób, w jaki Berkeley posługuje się modelem ND, można utożsamić, jak tego pragnie, z wyjaśnianiem. Głównym analizowanym przeze mnie tekstem jest De Motu (1721).

Słowa kluczowe: model ND, wyjaśnianie, grawitacja, przyczyna 